\title{
Phytoplankton Communities and Cyanotoxin Production in Some Bulgarian Lowland Lakes and Reservoirs
}

\author{
Zespoły fitoplanktonu i produkcja cyjanotoksyn w wybranych nizinnych jeziorach \\ i zbiornikach Bułgarii
}

\author{
Detelina Belkinova ${ }^{1,2}$, Ivanka Teneva ${ }^{2}$, Stefan Kazakov ${ }^{1}$, Silvia Stamenova ${ }^{2}$ \\ ${ }^{1}$ Institute of Biodiversity and Ecosystem Research, Bulgarian Academy of Sciences, Bulgaria \\ ${ }^{2}$ Faculty of Biology, Paisii Hilendarski University of Plovdiv, Bulgaria \\ ORCID DB https://orcid.org/0000-0003-0738-4871; IT http://orcid.org/0000-0002-8516-181X; SK https://orcid.org/0000-0001-6078-2938 \\ - detbel18@gmail.com \\ Received: 20 Oct, 2021; Revised: 29 Nov, 2021; Accepted: 6 Dec, 2021
}

\begin{abstract}
One of the most evident consequences of eutrophication of waters is the progressive spreading of persistent cyanobacterial blooms. They are often accompanied by the production of cyanotoxins in concentrations, which are hazardous for human health. In this research, we analysed phytoplankton communities in four lowland water bodies, for the presence of cyanobacterial blooms and toxin production. The cyanobacterial biovolumes we found, determine three of the lowland water bodies: Onogur Reservoir (OR), Asparuhov Val Reservoir (AVR), and Srebarna Lake (SL) as "Alert Level $1^{\prime \prime}$ of potentially hazardous levels of cyanotoxins. Cyanobacterial biovolume exceeds the threshold value of $8 \mathrm{~mm}^{3} \mathrm{~L}^{-1}$ (recreational waters) in AVR and SL at the end of the summer period. In OR, we registered sustainable bloom of Microcystis spp. during the whole summer season, and extremely high average seasonal value of the total biovolume $\left(146.5 \mathrm{~mm}^{3} \mathrm{~L}^{-1}\right)$. Microcystins were reported in all four analysed water bodies, with the highest concentration in $O R\left(6 \mu \mathrm{L} \mathrm{L}^{-1}\right)$. Cylindrospermopsin was detected in AVR and OR, while saxitoxins were in AVR and SL. The concentrations of cyanotoxins do not exceed the guideline values in recreational waters. However, the increased biovolumes of cyanobacteria are a signal that in three of the analysed water bodies, monitoring is recommended at the levels of cyanotoxins during the summer period.
\end{abstract}

Keywords: phytoplankton, cyanobacterial blooms, cyanotoxins, monitoring

Streszczenie: Najbardziej widocznym efektem eutrofizacji wód są coraz obszerniejsze i dłużej utrzymujące się zakwity sinic. Często towarzyszy im produkcja cyjanotoksyn w stężeniach niebezpiecznych dla zdrowia człowieka. W niniejszej pracy analizowaliśmy zespoły fitoplanktonu w czterech nizinnych zbiornikach wodnych pod kątem występowania zakwitów sinicowych i produkcji toksyn. Na podstawie badań bioobjętości sinic określono stopień potencjalnego ryzyka związanego z produkcją niebezpiecznych stężeń cyjanotoksyn w dwóch zbiornikach Onogur (OR) i Asparuhov Val (AVR) oraz w jeziorze Srebarna (SL). Stopień ryzyka w tych akwenach określono na poziomie alarmowym 1 "Alert Level 1". Pod koniec okresu letniego w AVR i SL bioobjętość sinic przekroczyła wartość progową $8 \mathrm{~mm}^{3} \mathrm{~L}^{-1}$ (dla wód rekreacyjnych). W OR odnotowaliśmy stały zakwit Microcystis spp. przez cały sezon letni i wyjątkowo wysoką średnią sezonową wartość całkowitej bioobjętości $\left(146,5 \mathrm{~mm}^{3} \mathrm{~L}^{-1}\right)$. Mikrocystyny wykryto we wszystkich czterech badanych zbiornikach wodnych, przy czym najwyższe stężenie odnotowano w OR (6 $\left.\mu \mathrm{g} \mathrm{L} \mathrm{L}^{-1}\right)$. Cylindrospermopsynę wykryto w AVR i OR, natomiast saksytoksyny - w AVR i SL. Stwierdzone stężenia cyjanotoksyn nie przekraczają wartości dopuszczalnych w wodach rekreacyjnych. Jednak zwiększone 
bioobjętości sinic wskazują, że w trzech z czterech analizowanych zbiorników wodnych należałoby monitorować poziom cyjanotoksyn w okresie letnim.

Słowa kluczowe: fitoplankton, zakwity cyjanobakterii, cyjanotoksyny, monitoring

\section{Introduction}

The ecological significance of phytoplankton is defined by the fact that the parameters of its productivity, are also indicators for the trophic condition of the water pool. The first organisms affected by the changes in lake ecosystems, connected to the process of eutrophication, are autotrophic organisms, which are the primary source in the food chain (Belkinova et al. 2013, 55).

Due to the short generation time of phytoplankton, its response to changes in the aquatic environment, mainly to the enrichment of the lakes in nutrients, is rapid and direct. (WFD CIS Guidance Document 23/2009, art. 4.1). Phytoplankton can be an early warning indicator and, theoretically, can be used to control subsequent changes in aquatic environment. Owing to the constant threat of excessive eutrophication of the aquatic environment, which is the main pressure in many countries, the knowledge of planktonic algae and cyanobacteria is gaining in importance. The response of phytoplankton to eutrophication has many negative effects (Pasztaleniec 2016, 26). Usually, it is manifested in its increased abundance and biomass, and contributes to greater turbidity of waters. As a result, a large number of secondary effects are observed, for example, changes in the taxonomic composition of the phytoplankton, excessive development of cyanobacteria and filamentous green algae, decreased colonisation depth of macrophytes, and even their complete withdrawal. Persistent cyanobacterial blooms, including those of toxic species, occur (Chorus and Welker 2021, 3).

The above mentioned changes cause socio-economic consequences: deterioration of the water quality of recreational lakes/ reservoirs, a ban on swimming (because of blooms), death of fish (caused by anoxia), or unsuitability of fish for consumption, as a result of their content of toxins, harmful impact on drinking water, and decline of the natural values of protected areas (Pasztaleniec 2016, 26).

Cyanobacterial blooms are a global threat to the sustenance of water ecosystems, which affects human health and the economy. Blooms can definitely limit the use of water, due to the possible production of toxins (Napiórkowska-Krzebietke 2015, 98). In the past few years, the assessment of the threshold of cyanobacterial bloom has turned into one of the most studied values used for the assessment of the ecological state of water bodies, and for the determination of human health risk.

In 1999, the World Health Organisation (WHO) developed its first drinking-water guidelines value for the widely spread cyanobacterial toxin, microcystin-LR. Since 1999, the knowledge on cyanotoxins has grown exponentially, and this has allowed the development of guideline values for the other cyanotoxins (Chorus and Welker 2021, ix).

The global significance of the problem stimulates the performance of scientific research on the problems connected to cyanotoxins in Bulgaria as well, as they have been actively studied since 2009. In the summary of part of the results for a 15-year period of time, (Stoyneva-Gärtner et al. 2017), 149 state that in 16 out of 120 Bulgarian reservoirs, there are reported cyanotoxins, including in 3 drinking water reservoirs. A number of analyses on phytoplankton, during the past few years, have reported increased frequency of cyanobacterial blooms in Bulgarian reservoirs (Dochin and Stoyneva 2016, 59).

The aim of this research is to expand the knowledge of the problem in Bulgaria, through analysis of phytoplankton 
communities, for the presence of cyanobacterial blooms and toxin levels in four lowland water bodies. To achieve this goal, we: (i) studied the taxonomic composition, and the species' richness of phytoplankton; (ii) determined the biovolume of phytoplankton and descriptor species; (iii) analysed the seasonal succession of phytoplankton in taxonomic groups; (iv) measured the concentration of cyanotoxins in the water samples.

\section{Materials and methods}

\subsection{Description of the water bodies and morphometric characteristics}

The main objects of the study were the lowland reservoirs Onogur (OR), Asparuhov Val (AVR), Lomtsi (LR), and Srebarna Lake (SL) - Fig. 1. They are situated in North Bulgaria and are characterised as shallow polymictic water bodies (Table 1). The most essential economical applications of these reservoirs are irrigation, fishing, fish-farming, and recreation. SL is the largest Bulgarian lake, near the Danube, and has protection status.

\subsection{Phytoplankton sampling}

The analysis of phytoplankton was performed with an integrated sample, representing a euphotic zone, in accordance with ISO 5667-1:2020. Four samples were taken from the studied water bodies in the summer of 2019 (months: June, July, August, and September),

The following physico-chemical parameters: water temperature, transparency (Secchi disk), dissolved oxygen, conductance, and $\mathrm{pH}$, were measured in situ, with the use of calibrated field devices. The concentration of chlorophyll- $a$ was specified under the confirmed spectrophotometric method, following ISO 10260:1992.

\subsection{Phytoplankton analyses}

The taxonomic composition of phytoplankton was determined by a light microscope Magnum (up to $1000 \times$ magnification). The general taxonomic system follows Guiry and Guiry (2021). Phytoplankton counting was performed with an inverted microscope (Utermöhl 1958). At least 1,ooo individuals of the most numerous species in each sample were counted (Padisák et al. 2006, 4). Algal biovolume was calculated with

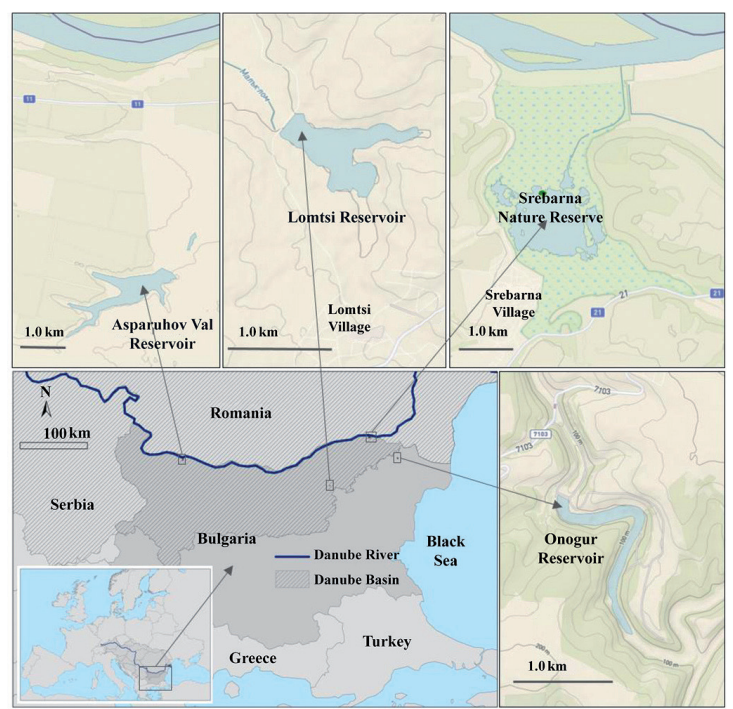

Figure 1. Map of the location of the investigated water bodies. Large-scale topographic maps of the water bodies were obtained from https://ngmdb.usgs.gov and modified. Arrows designate the sampling stations 
Table 1. Morphometric characteristics and economic use of the studied reservoirs/lakes. PS protection status. The data is according to Michev and Stoyneva (2007)

\begin{tabular}{lcccc}
\hline \multicolumn{1}{c}{ Characteristics } & Onogur & Asparuhov val & Srebarna & Lomtsi \\
\hline Latitude & 43.82095 & 43.74828 & 44.10714 & 43.44719 \\
Longitude & 27.59759 & 23.63183 & 27.0731 & 26.34533 \\
\hline Altitude $(\mathrm{m}$ a.s.l.) & 93 & 133 & $10.0-13.2$ & 205 \\
\hline Surface area $\left(\mathrm{km}^{2}\right)$ & 0.09 & 1.3 & 10 & 0.7 \\
\hline Maximal depth $(\mathrm{m})$ & 1.0 & 6.0 & 3.3 & 5.0 \\
\hline Mictic type & Polymictic & Polymictic & Polymictic & Polymictic \\
\hline Volume $\left(\mathrm{km}^{3}\right)$ & - & 0.0081 & 2.81/14.35 & low/high level \\
& & & International PS: & Irrigation, \\
\hline Use & Irrigation, & Irrigation, & Biosphere Reserve, & Fish-farming \\
& Fishing, & Fish-farming, & Ramsar Site & \\
& Recreation, & Fishing & & \\
& Watering animals & & &
\end{tabular}

geometric-shape formulas (Hillebrand et al. 1999). The total biovolume of phytoplankton in each sample was calculated by summation of the biovolumes of all taxa. The selected descriptor species were those with relative biovolume of $>5 \%$ of the total biovolume of the phytoplankton. The dominant taxonomic groups we accepted, were the ones with at least $50 \%$ of the total biovolume.

\subsection{Analysis for presence of cyanotoxins}

The analysis of the water samples for presence of microcystins and nodularins was performed with Microcystins/Nodularins (ADDA) ELISA kit (Abraxis LLC, Warminster, PA), under the prescriptions and the protocols of the manufacturers. This is an enzyme-linked immunosorbent assay (ELISA) for a quantitative analysis of microcystins and nodularins in water samples. The borderline detection of the Microcystins ELISA kit is $0.10 \mathrm{ppb}\left(\mu \mathrm{g} \mathrm{L}^{-1}\right)$. ELISA kits of the same company, were used for the detection of saxitoxins and cylindrospermopsin - ELISA Kit (PN 52255B), with detection limit of $0.02 \mathrm{ppb}\left(\mu \mathrm{g} \mathrm{L}{ }^{-1}\right)$, and Cylindrospermopsin ELISA Kit (PN 522011), with detection limit of $0.05 \mathrm{ppb}\left(\mu \mathrm{g} \mathrm{L}^{-1}\right)$, respectively. The intensity of the blue colour, is in inverse proportion to the concentration of microcystins, cylindrospermopsin, or saxitoxins, available in the sample. The report is performed with the use of ELISA reader ELx80oTM (BioTek) at $450 \mathrm{~nm}$. The concentrations of cyanotoxins in the samples were specified with the use of a standard curve, designed for each report.

\section{Results}

\subsection{Physico-chemical parameters and concentration of chlorophyll-a}

The values of physico-chemical parameters in the analysed water bodies are presented in Table 2. The average values of water temperature vary from 23.0 to $27.1^{\circ} \mathrm{C}$ and are typical for the summer season, in the lakes of the temperate zone. The active reaction of water in the four lakes is in the alkaline region and varies from 8.03 to 10.14. The average values of oxygen concentration in OR, AVR, and LR are more than $100 \%$, which means supersaturation in a greater part of the summer season. In connection to the intensive bloom of phytoplankton in OR, we reported supersaturation (up to $200 \%$ ) in the waters during almost the whole analysed period, and very low transparency $(0.04 \mathrm{~m})$.

Regarding the concentration of chlorophyll- $a$, an extremely high value was 
detected in OR, in September - $5183 \mu \mathrm{g} \mathrm{L}^{-1}$. The average seasonal concentration of chlorophyll- $a$ in this reservoir was 50 times over the values of chlorophyll- $a$ in the other lakes.

\subsection{Taxonomic composition and phytoplankton species' richness}

We found a total of 162 phytoplankton species in the four studied water bodies, which are related to 9 taxonomic groups (Fig. 2): Cyanobacteria, Chlorophyta, Charophyta, Bacillariophyta, Cryptophyta, Chrysophyceae, Eustigmatophyceae, Euglenophyceae Dinophyceae.

During the whole summer season, the predominant number of species in OR are $\mathrm{Cy}$ anobacteria and Green Algae (Chlorophyta), which totals over $80 \%$ of the species (Fig. 2). The taxonomic composition of phytoplankton in AVR and SL excels with a greater species richness ( 80 and 108 species, respectively), which is distributed in twice the more taxonomic groups. In both water bodies, during the whole summer season, Cyanobacteria and Green algae are the dominant and the codominant species (Fig. 2). In terms of their differences, Green algae are distinctly predominant in LR in the whole summer season (35 to $55 \%$ of species richness). Only in the middle of the summer (July and August), is there a significant percentage of Cyanobacteria (26\% and 25\%, respectively).

\subsection{Descriptor species and biovolume of phytoplankton}

During the period of analysis in OR, we detected an extremely high average value of the total biovolume $\left(146.5 \mathrm{~mm}^{3} \mathrm{~L}^{-1}\right)$, which exceeds the average values in AVR, SL, and LR from 11 to 24 times $(12.8,7.0$, and 6.1 $\mathrm{mm}^{3} \mathrm{~L}^{-1}$, respectively) - Table 3 . The intensive bloom of Microcystis flosaquae is a characteristic feature of the phytoplankton community in OR, with an individual biovolume for each month - 71.9, 29.1, 34.6, and $110.0 \mathrm{~mm}^{3} \mathrm{~L}^{-1}$, respectively. In the middle, and at the end of the summer, the additional codominant blooming species were $M$. aeruginosa and $M$. wesenbergii (Table 3 ). In September, these potentially toxic species of Microcystis formed $82 \%$ of the total biovolume. The biovolume of phytoplankton in AVR had a rapid increase in the summer season, reaching a peak in September $39.0 \mathrm{~mm}^{3} \mathrm{~L}^{-1}$. In the middle, and at the end of the summer, eutrophic cyanobacteria, Sphaerospermopsis aphanizomenoides (55\% relative biovolume), Planktothrix agardhii (19\%), Raphidiopsis raciborskii (6\%), and Planktolyngbya limnetica (5\%), replaced the other species, and remained the only descriptor species. The peak of the total biovolume of $39.0 \mathrm{~mm}^{3} \mathrm{~L}^{-1}$ reported in September, was a result of blooms of potentially toxic species $-P$. agardhii $\left(27.6 \mathrm{~mm}^{3} \mathrm{~L}^{-1}\right)$ and $R$. raciborskii $\left(3.2 \mathrm{~mm}^{3} \mathrm{~L}^{-1}\right)$. The sum of both species formed $79.0 \%$ of the total biovolume. Similar to AVR in SL, we observed

Table 2. Physico-chemical parameters and concentrations of chlorophyll- $a$ in the analysed reservoirs/ lakes in 2019. WT-water temperature; SD-Secchi depth; DO-dissolved oxygen; OS-oxygen saturation; C-conductivity; Chl- $a$-chlorophyll- $a$. In bold - average values of the parameters

\begin{tabular}{lrrrrrrr}
\hline Water bodies & $\mathrm{WT}\left({ }^{\circ} \mathrm{C}\right)$ & \multicolumn{1}{c}{$\mathrm{SD}(\mathrm{m})$} & \multicolumn{1}{c}{$\mathrm{pH}$} & $\mathrm{DO}\left(\mathrm{mg} \mathrm{L}^{-1}\right)$ & $\mathrm{OS}(\%)$ & $\mathrm{C}\left(\mu \mathrm{S} \mathrm{cm}{ }^{-1}\right)$ & $\mathrm{Chl}-\mathrm{a}\left(\mu \mathrm{g} \mathrm{L}^{-1}\right)$ \\
\hline Onogur & $\mathbf{2 3 . 8}$ & $\mathbf{0 . 0 4}$ & $\mathbf{1 0 . 1 4}$ & $\mathbf{1 8 . 8}$ & $\mathbf{1 9 0 . 0}$ & $\mathbf{9 4 6}$ & $\mathbf{4 1 5 3 . 8}$ \\
\cline { 2 - 8 } min-max & $15.1-29.7$ & $0.02-0.05$ & $9.95-10.36$ & $15.78-20.0$ & $160.0-200.0$ & $720-1390$ & $3139.4-5182.9$ \\
\hline Asparuhov Val & $\mathbf{2 7 . 1}$ & $\mathbf{0 . 4 1}$ & $\mathbf{9 . 0 1}$ & $\mathbf{1 0 . 1 3}$ & $\mathbf{1 2 8 . 5}$ & $\mathbf{9 5 3}$ & $\mathbf{8 2 . 4}$ \\
\cline { 2 - 8 } min-max & $23.3-30.0$ & $0.22-0.75$ & $9.03-9.09$ & $4.42-14.55$ & $55.0-195.0$ & $925-992$ & $32.6-112.5$ \\
\hline Srebarna & $\mathbf{2 4 . 2}$ & $\mathbf{0 . 8 9}$ & $\mathbf{8 . 0 3}$ & $\mathbf{6 . 4}$ & $\mathbf{7 8 . 5}$ & $\mathbf{4 0 6}$ & $\mathbf{5 1 . 9}$ \\
\cline { 2 - 8 } min-max & $21.2-25.4$ & $0.5-1.5$ & $7.54-8.81$ & $1.45-11.96$ & $18.0-147.0$ & $346-479$ & $6.51-80.95$ \\
\hline Lomtsi & $\mathbf{2 3 . 0}$ & $\mathbf{0 . 5 3}$ & $\mathbf{8 . 8 8}$ & $\mathbf{1 1 . 6}$ & $\mathbf{1 3 4 . 5}$ & $\mathbf{6 2 0}$ & $\mathbf{7 8 . 6}$ \\
\cline { 2 - 8 } min-max & $21.0-25.5$ & $0.35-0.8$ & $8.43-9.59$ & $7.35-18.2$ & $85.0-200.0$ & $594-647$ & $48.1-108.9$ \\
\hline
\end{tabular}



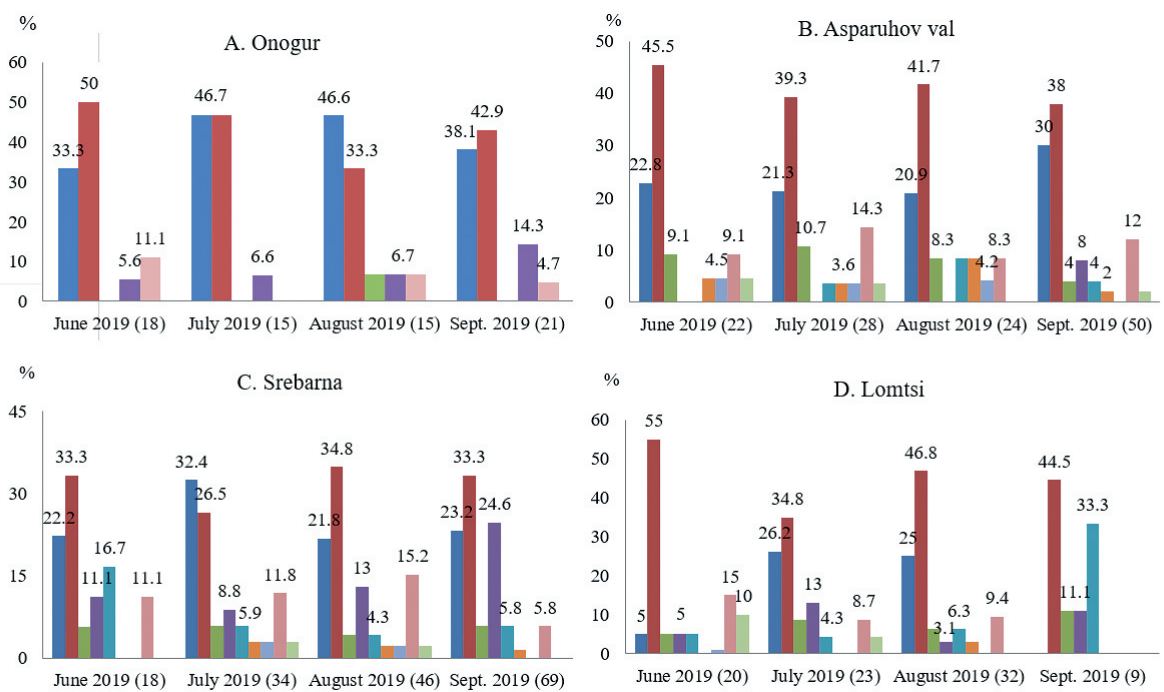

Figure 2. Species richness (\%) of phytoplankton for different taxonomic group in the four studied water bodies. In the brackets, the total number of phytoplankton species for each month is presented

a sharp increase of the total biovolume of phytoplankton from June to September, as well (from 0.7 to $13.0 \mathrm{~mm}^{3} \mathrm{~L}^{-1}$ ). The descriptor species were different for each month of the summer period. However, as with AVR, in SL, there was an intensive development of eutrophic cyanobacteria Cuspidothix issatschenkoi $\left(3.0 \mathrm{~mm}^{3} \mathrm{~L}^{-1}\right)$ and Aphanizomenon flosaquae $\left(2.3 \mathrm{~mm}^{3} \mathrm{~L}^{-1}\right)$ in the middle, and at the end of the summer. They formed a sum of $40 \%$ of the total biovolume in September. The average seasonal value of biovolume in LR was the lowest and varied slightly in the summer season (from 4.3 to $7.6 \mathrm{~mm}^{3} \mathrm{~L}^{-1}$ ). The seasonal succession of descriptor species also revealed more differences. Cryptophytic algae Cryptomonas erosa (49\%) and diatom species, Aulacoseira granulata (61\%), respectively, had the largest biovolume in June and July. Cyanobacteria $P$. agardhii and $M$. aeruginosa appeared as descriptor species of phytoplankton, only in August. In September, there was an intensive development of C. erosa, which concentrated more than half (58\%) of the total biovolume.

\subsection{Seasonal succession of phytoplankton by taxonomic groups}

In OR, Cyanobacteria was a dominant taxonomic group during the whole summer season, as its representatives were concentrated from 54 to $95 \%$ of the total biovolume (Fig. 3). At the beginning of the summer (June), the biovolume of phytoplankton in AVR had an equal distribution between relatively large number of taxonomic groups: Charophyta, Euglenophyceae, Cyanobacteria, Chlorophyta, and Chrysophyceae (with relative biovolumes of $27,26,23,15$, and $7 \%$, respectively). In the middle, and at the end of the summer, cyanobacteria replaced the other taxonomic groups, and remained the only dominant group, with a relative biovolume of $89 \%$. The seasonal succession of biovolume was similar in SL. At the beginning of summer, the total biovolume of phytoplankton was formed by a large number of taxonomic groups: Chlorophyta, Bacillariophyta, Cyanobacteria, Euglenophyceae, and Cryptophyta (with relative biovolumes of 40 , $19,16,12$, and $12 \%$, respectively). Within the summer season, the relative biovolume of Cyanobacteria increased from $16 \%$ in June to $60 \%$ in September. A specific feature of the phytoplankton community in LR is 
Table 3. Descriptor phytoplankton species in the studied water bodies

\begin{tabular}{|c|c|c|c|}
\hline Descriptor species & Taxonomic group & $\mathrm{IBv}\left(\mathrm{mm}^{3} \mathrm{~L}^{-1}\right)$ & $\operatorname{RBv}(\%)$ \\
\hline \multicolumn{4}{|c|}{ Onogur: $159.0 / 50.9 / 64.0 / 312.2^{\star}(146.5)$} \\
\hline Limnococcus limneticus & $\mathrm{Cy}$ & $0 / 13.8 / 6.9 / 0.5$ & $0 / 27.0 / 10.7 / 0$ \\
\hline Microcystis aeruginosa & Cy & o/0/0/131.8 & $0 / 0 / 0 / 42.2$ \\
\hline Microcystis flosaquae & Cy & 71.0/29.1/34.6/110.9 & $45.3 / 57.1 / 54.0 / 35.5$ \\
\hline Microcystis wesenbergii & Cy & $0 / 0 / 8.1 / 12.4$ & $0 / 0 / 12.6 / 4.0$ \\
\hline Synechocystis aquatilis & Cy & $9.3 / 1.3 / 0 / 0$ & $5.8 / 2.6 / 0 / 0$ \\
\hline Golenkinia radiata & $\mathrm{Chl}$ & $0 / 0 / 0 / 17.2$ & $0 / 0 / 0 / 5.5$ \\
\hline Pseudopediastrum boryanum & $\mathrm{Chl}$ & $50.8 / 0.9 / 1.6 / 4.7$ & $32.0 / 1.8 / 2.4 / 1.5$ \\
\hline Fragilaria sp. & $\mathrm{Ba}$ & $13.5 / 1.1 / 0 / 3.1$ & $8.5 / 2.2 / 0 / 1.0$ \\
\hline Euglena texta & $\mathrm{Eu}$ & $0 / 0 / 4.2 / 6.1$ & 0/0/6.6/1.9 \\
\hline \multicolumn{4}{|c|}{ Asparuhov val: $1.8 / 6.0 / 4.3 / 39.0^{*}(12.8)$} \\
\hline Dolichospermum flosaquae & $\mathrm{Cy}$ & $0.3 / 0.2 / 0 / 0$ & $15.3 / 2.6 / 0 / 0$ \\
\hline Microcystis flosaquae & Cy & $0 / 0.4 / 0 / 0$ & $0 / 6.9 / 0 / 0$ \\
\hline Microcystis wesenbergii & Cy & $0 / 0.5 / 0 / 0$ & 0/8.0/0/0 \\
\hline Planktolyngbya limnetica & Cy & $0.0002 / 0.2 / 0.2 / 1.9$ & $0 / 3.9 / 5.4 / 4.8$ \\
\hline Planktothrix agardhii & Cy & $0 / 0 / 0.8 / 27.6$ & $0 / 0 / 19.2 / 70.8$ \\
\hline Raphidiopsis raciborskii & Cy & $0 / 0 / 0.3 / 3.2$ & $0 / 0 / 6.0 / 8.2$ \\
\hline Sphaerospermopsis aphanizomenoides & Cy & $0 / 0.2 / 2.4 / 0.2$ & $0 / 4.0 / 54.7 / 0.6$ \\
\hline Sphaerospermopsis kisseleviana & Cy & $0.1 / 0.4 / 0 / 0$ & $4.8 / 6.7 / 0 / 0$ \\
\hline Actinastrum hantzschii & $\mathrm{Chl}$ & $0.1 / 0.0001 / 0 / 0.05$ & $5.0 / 0 / 0 / 0.001$ \\
\hline Cosmarium sp. & Cha & $0.1 / 0 / 0 / 0.7$ & $7.2 / 0 / 0 / 1.9$ \\
\hline Staurastrum gracile & Cha & $0.4 / 0.1 / 0.02 / 0$ & $19.9 / 2.2 / 0.4 / 0$ \\
\hline Chrysococcus rufescens & Chr & $0.1 / 0.2 / 0 / 0$ & $7.2 / 2.6 / 0 / 0$ \\
\hline Euglenaformis proxima & $\mathrm{Eu}$ & $0 / 1.6 / 0 / 0$ & $0 / 26.3 / 0 / 0$ \\
\hline Lepocinclis acus & $\mathrm{Eu}$ & $0.3 / 0.3 / 0 / 0$ & $16.0 / 4.8 / 0 / 0$ \\
\hline Lepocinclis caudata & $\mathrm{Eu}$ & $0 / 0.4 / 0.005 / 0.3$ & $0 / 6.6 / 0.1 / 0.9$ \\
\hline Trachelomonas volvocina & $\mathrm{Eu}$ & $0.2 / 0.3 / 0 / 0.02$ & $9.6 / 4.3 / 0 / 0.1$ \\
\hline Ceratium furcoides & $\mathrm{D}$ & $0 / 0.4 / 0 / 0$ & $0 / 6.5 / 0 / 0$ \\
\hline \multicolumn{4}{|c|}{ Srebarna: $0.7 / 2.4 / 11.7 / 13.0^{*}(7.0)$} \\
\hline Aphanizomenon flosaquae & $\mathrm{Cy}$ & $0.08 / 0.2 / 0.04 / 2.3$ & $12.9 / 6.7 / 0.3 / 17.6$ \\
\hline Cuspidothix issatschenkoi & $\mathrm{Cy}$ & $0 / 0 / 0.6 / 3.0$ & $0 / 0 / 4.7 / 22.7$ \\
\hline Raphidiopsis raciborskii & Cy & $0 / 0.2 / 0 / 0.04$ & $0 / 6.4 / 0 / 0.3$ \\
\hline Limnothrix planctonica & Cy & $0 / 0.1 / 0.2 / 0.8$ & $0 / 4.8 / 2.0 / 6.4$ \\
\hline Microcystis aeruginosa & Cy & $0 / 0.3 / 0 / 0.1$ & $0 / 13.7 / 0 / 1.0$ \\
\hline Oscillatoria sancta & Cy & $0 / 0 / 2.0 / 0.2$ & 0/0/17.1/1.4 \\
\hline Romeria gracillis & Cy & $0 / 0.1 / 0.06 / 0$ & $0 / 6.0 / 0.5 / 0$ \\
\hline Dictyosphaerium sp. & $\mathrm{Chl}$ & $0.2 / 0.08 / 0.1 / 0.1$ & $33.5 / 3.5 / 1.3 / 0.8$ \\
\hline Bacillaria paxillifera & $\mathrm{Ba}$ & $0 / 0 / 4.7 / 0.03$ & $0 / 0 / 40.4 / 0.2$ \\
\hline Cymbella sp. & $\mathrm{Ba}$ & $0 / 0 / 0 / 0.8$ & $0 / 0 / 0 / 6.3$ \\
\hline Epithemia sp. & $\mathrm{Ba}$ & $0.1 / 0.1 / 0 / 0$ & $14.5 / 3.2 / 0 / 0$ \\
\hline Euglenaria caudata & $\mathrm{Eu}$ & $0 / 0 / 0.8 / 0.9$ & $0 / 0 / 7.0 / 7.0$ \\
\hline Euglena sp. & $\mathrm{Eu}$ & $0.04 / 0.03 / 0 / 0$ & $5.8 / 1.3 / 0 / 0$ \\
\hline Lepocinclis sp. & $\mathrm{Eu}$ & $0.04 / 0 / 0 / 0$ & $5.8 / 0 / 0 / 0$ \\
\hline Kolkwitziella acuta & $\mathrm{D}$ & $0 / 0.6 / 0 / 0$ & $0 / 26.5 / 0 / 0$ \\
\hline Chroomonas coerulea & $\mathrm{Cr}$ & $0.04 / 0.06 / 0 / 0.01$ & $5.6 / 2.6 / 0 / 0.1$ \\
\hline Plagioselmis nannoplanctica & $\mathrm{Cr}$ & $0.03 / 0 / 0 / 0.01$ & $5.1 / 0 / 0 / 0.9$ \\
\hline
\end{tabular}




\begin{tabular}{|c|c|c|c|}
\hline Descriptor species & Taxonomic group & $\operatorname{IBv}\left(\mathrm{mm}^{3} \mathrm{~L}^{-1}\right)$ & $\operatorname{RBv}(\%)$ \\
\hline \multicolumn{4}{|c|}{ Lomtsi: 4.3/7.6/6.7/5.8*(6.1) } \\
\hline Microcystis aeruginosa & $\mathrm{Cy}$ & $0 / 0 / 0.5 / 0$ & $0 / 0 / 7.2 / 0$ \\
\hline Planktothrix agardhii & Cy & $0 / 0.3 / 1.3 / 0$ & $0 / 3.6 / 19.4 / 0$ \\
\hline Actinastrum hantzschii & $\mathrm{Chl}$ & 0/0.0001/0.9/0 & $0 / 0.001 / 14.2 / 0$ \\
\hline Lemmermannia tetrapedia & $\mathrm{Chl}$ & $0.2 / 0.01 / 0.01 / 0$ & $5.8 / 0.2 / 0.2 / 0$ \\
\hline Monactinus simplex & $\mathrm{Chl}$ & $0 / 0 / 0 / 0.9$ & 0/0/0/15.6 \\
\hline Pediastrum duplex & $\mathrm{Chl}$ & $0 / 0 / 1.2 / 0$ & $0 / 0 / 18.4 / 0$ \\
\hline Closterium sp. & Cha & $0 / 0 / 0.1 / 0.6$ & $0 / 0 / 1.5 / 11.2$ \\
\hline Aulacoseira granulata & $\mathrm{Ba}$ & $0 / 4.7 / 0 / 0$ & $0 / 61.3 / 0 / 0$ \\
\hline Navicula cryptotenella & $\mathrm{Ba}$ & $0 / 0 / 0 / 0.4$ & $0 / 0 / 0 / 6.6$ \\
\hline Euglenaformis proxima & $\mathrm{Eu}$ & $0.002 / 0.6 / 0 / 0$ & $0.1 / 7.5 / 0 / 0$ \\
\hline Lepocinclis sp. & $\mathrm{Eu}$ & $1.2 / 0 / 0 / 0$ & $27.1 / 0 / 0 / 0$ \\
\hline Peridiniopsis cunningtonii & $\mathrm{D}$ & $0.7 / 0 / 0 / 0$ & $15.7 / 0 / 0 / 0$ \\
\hline Kolkwitziella acuta & D & $0 / 1.0 / 0 / 0$ & $0 / 13.0 / 0 / 0$ \\
\hline Cryptomonas erosa & $\mathrm{Cr}$ & $2.1 / 0 / 0.5 / 3.4$ & $49.0 / 0 / 7.8 / 58.9$ \\
\hline
\end{tabular}

Taxonomic groups: Cy-Cyanobacteria; Chl- Chlorophyta; Cha- Charophyta; Ba- Bacillariophyta; Cr-Cryptophyta; ChrChrysophyceae; Eus- Eustigmatophyceae; Eu- Euglenophyceae; D- Dinophyceae; *Total biovolumes of phytoplankton $\left(\mathrm{mm}^{3} \mathrm{~L}^{-1}\right)$ in the samples from June/July/August/September; IBv-Individual biovolumes of phytoplankton species in the samples from June/July/August/September; RBv-Relative biovolumes of phytoplankton species from the total biovolume in the samples from June/July/August/September; in brackets - average seasonal biovolume $\left(\mathrm{mm}^{3} \mathrm{~L}^{-1}\right)$

that the summer season started and finished with the dominance of cryptophytic algae, with a relative biovolume of $49 \%$ (June) and $64 \%$ (September). In difference to the other lakes, cyanobacteria took a significant part of the biovolume of phytoplankton, only in August (37\%), and they were totally missing at the end of the summer.

\subsection{Analysis of the water samples for presence of cyanotoxins}

During the analysis of seasonal dynamics of phytoplankton biovolume, we found that in three of the analysed water bodies (OR, AVR, and SL), cyanobacterial biovolume reaches, or exceeds, the values of "Alert Level 1" (Chorus and Testai 2021, 350-351) Fig. 4. This motivated the water sampling for analysis of toxins, from all studied water bodies in September, 2019. The results from the analysis are summarised and presented in Table 4.

The water samples from OR show a presence of hepatotoxins in both analysed groups - mictocystins and cylindrospermopsin, in concentrations of $6.5 \mathrm{\mu g} \mathrm{L}^{-1}$ and $0.10 \mu \mathrm{g} \mathrm{L}^{-1}$, respectively (Table 4 ).
The presence of microcystins is a result of the reported cyanobacterial species M. aeruginosa, M. flosaquae, and M. wesenbergii (Table 3), which have been repeatedly reported in the scientific literature, as producers of microcystins. The cylindrospermopsin reported in the water sample (0.10 $\left.\mu \mathrm{g} \mathrm{L}^{-1}\right)$ is most probably a result of the presence of Limnothrix redekei. Neurotoxins from the group of saxitoxins were not detected.

AVR is the only one of the studied water bodies, in which we reported all the three types of cyanotoxins. The concentration of microcystins was 3 times lower than the one in $\mathrm{OR}-2 \mu \mathrm{g} \mathrm{L}^{-1}$. They are produced by $P$. agardhii, which was blooming, and took $70.8 \%$ of the total biovolume of phytoplankton (Table 3). The presence of cylindrospermopsin (at an amount of $0.15 \mu \mathrm{g} \mathrm{L}{ }^{-1}$ ) can be explained with the cyanobacteria $R$. raciborskii and L. redekei found in phytoplankton samples. The saxitoxins reported in the water samples were in a concentration of $0.02 \mu \mathrm{g} \mathrm{L} \mathrm{L}^{-1}$. The producer of these toxins in reservoirs is probably A. flosaquae, which is a proved producer of neurotoxins. 

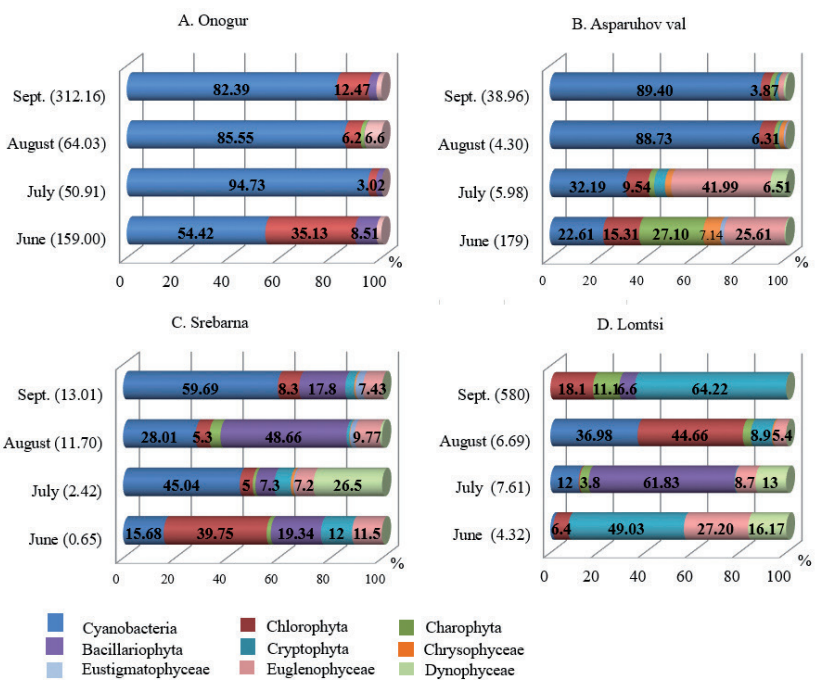

Figure 3. Seasonal variation of the relative biovolume (\%) of phytoplankton presented by taxonomic groups in 2019. The total biovolume of phytoplankton for each month is specified in brackets

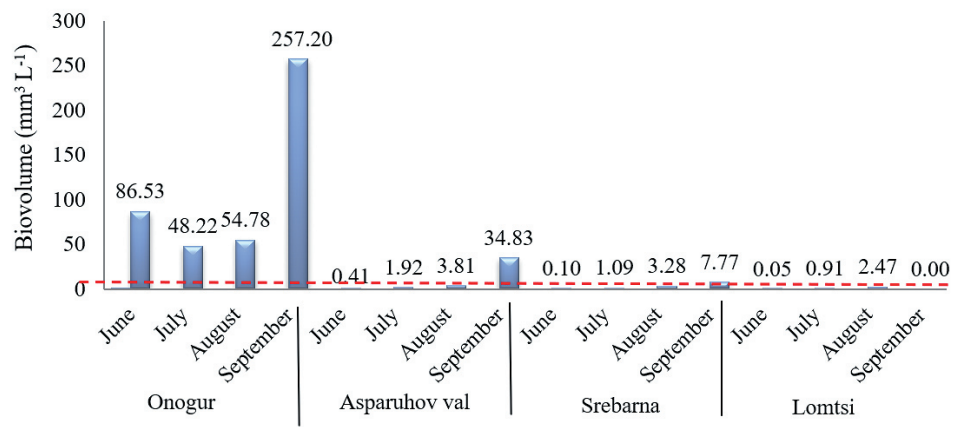

Figure 4. Seasonal distribution of cyanobacterial biovolume in the four water bodies in Bulgaria in 2019. Red line - upper threshold for "Alert Level 1", with biovolume of up to $8 \mathrm{~mm}^{3} \mathrm{~L}^{-1}$ in recreational waters

Table 4. Quantitative and qualitative composition of cyanotoxins in the studied water bodies

\begin{tabular}{lcccc}
\hline \multicolumn{1}{c}{ Cyanotoxins } & Onogur & Asparuhov val & Srebarna & Lomtsi \\
\hline Microcystins $\left(\mu \mathrm{L} \mathrm{L}^{-1}\right)$ & 6.5 & 2 & 0.2 & 0.17 \\
\hline Cylindrospermopsin $\left(\mu \mathrm{g} \mathrm{L}^{-1}\right)$ & 0.10 & 0.15 & - & - \\
\hline Saxitoxins $\left(\mu \mathrm{g} \mathrm{L}^{-1}\right)$ & - & 0.02 & 0.10 & - \\
\hline
\end{tabular}

We detected two types of cyanotoxins in SL: microcystins $\left(0.2 \mu \mathrm{g} \mathrm{L}^{-1}\right)$ and saxitoxins $\left(0.10 \mu \mathrm{g} \mathrm{L}^{-1}\right)$. The potential producer of these toxins is $A$. flosaquae, which reached a biovolume of $2.3 \mathrm{~mm}^{3} \mathrm{~L}^{-1}$ in September (Table 3). No cylindrospermopsin was reported in this water sample.

Despite the lack of cyanobacterial species in September, we reported a small amount of microcystins in LR - $0.17 \mu \mathrm{g} \mathrm{L} \mathrm{L}^{-1}$. Considering the fact that in August, we identified $M$. aeruginosa and $P$. agardhii as descriptor species (Table 3), we think that the presence of microcystins was a result of their decomposition. 


\section{Discussion}

The consequences of cyanobacterial blooms and the cyanotoxins have been actively studied in Bulgaria since 2009 (Teneva et al., 2009; 2010a, b; 2011; 2014; Pavlova et al. $2014 ; 2015)$. The summarised information for the current condition of this topic was provided by Teneva et al. 2015, 24124.2, Stoyneva-Gärtner et al. 2017, 131-149, and Descy et al. 2018, 47-49. The analysis of this problem is important, as the expansion of cyanobacterial blooms may have negative consequences on biodiversity, and on the functioning of water food chains, and threatens the use of affected waters for drinking, bathing, fishing, and recreation (WFD CIS Guidance Document 23/2009, 106; Pasztaleniec 2016, 26).

The results of the cyanotoxins monitoring, performed for a period of 15 years (from 2000 to 2015), include 120 Bulgarian reservoirs which are of different location, morphometry, and trophic state (Stoyneva-Gärtner et al. 2017, 131-133, 149). The analysis showed the following: 1 ) there is a great diversity of cyanobacteria in Bulgarian lakes (210 cyanobacterial taxa of 60 genera); 2) toxin species are found in 30 reservoirs; 3 ) cyanotoxins (microcystins, nodularins, and saxitoxins) are reported in 16 reservoirs; 4) the concentration of toxins varies between 0.1 and $26.5 \mu \mathrm{g} \mathrm{L}^{-1}$ in water samples, and between 10.9 and $1070 \mu \mathrm{g} \mathrm{L}^{-1}$ (d.w.) in concentrated (net) samples. Despite the facts that microcystins were not found in all studied water bodies, and that the registered levels of microcystins are lower than those in other European countries, the fact that there is a presence of cyanotixins in 3 drinking water reservoirs, may serve as a warning about the necessity of recognising cyanotoxins as a new health risk factor in the country.

The issue "Toxic Cyanobacteria in Water", published by the WHO in 1999, was the first one which offers "Alert Levels" connected to the exposition of cyanotoxins in recreational waters. In 2020 , the $\mathrm{WHO}$ reviewed the maximum acceptable concentrations for cyanotoxins. In relation to the new requirements, three "Indicative alert levels" connected to the exposition of cyanotoxins in recreational water and in drinking-water supply, were specified (Chorus and Testai 2021, 350-351; Humpage and Cunliffe 2021, 320-321). Different input parameters are offered for the assessment of the health risk of cyanotoxins, which vary from the visual evaluation, through microscopy and quantitative specification of cyanobacterial biomass, to toxin analysis.

The analysis of the results of our studies in all lowland water bodies showed the following specific features of phytoplankton communities. The phytoplankton in OR is characterised with the predominance of $\mathrm{Cy}$ anobacteria and Green algae, which form $80 \%$ of the species (Fig. 2). In OR, we reported an extremely high average seasonal value of the total biovolume $\left(146.5 \mathrm{~mm}^{3} \mathrm{~L}^{-1}\right)$, and persistent sustainable bloom of Microcystis spp. Cyanobacteria, are the dominant taxonomic groups during the whole summer season, with 54 to $95 \%$ contribution to the total biovolume (Fig. 3).

AVR and SL have similar seasonal succession of phytoplankton biovolume. At the end of the summer (in September), we registered a peak of the total phytoplankton biovolume, with blooms of potentially toxic species $P$. agardhii, $R$. raciborskii (in AVR) and C. issatschenkoi, A. flosaquae (in SL) - Table 3. In September, the relative biovolume of Cyanobacteria increases up to $89 \%$ in AVR, and up to $60 \%$ in SL (Fig. 3).

In the context of the new threshold values for alert levels, according to Chorus and Testai, 2021, 350-351, the cyanobacterial biovolumes established by us, place OR, AVR, and SL, in "Alert Level 1" for potentially hazardous levels of toxins. In SL and AVR, cyanobacterial biovolume reached and exceeded $8 \mathrm{~mm}^{3} \mathrm{~L}^{-1}$ in September, and in $\mathrm{OR}$, the situation was like that during the whole summer (Fig. 4). With the presence of a national policy of monitoring cyanotoxins in these water bodies, "Monitoring to trigger immediate responses" has 
to be applied, within the context of the new guidelines of the WHO. It is being realised when the "Vigilance Level" and the "Alert Level 1" are exceeded, and is conducted regularly (monthly or weekly), with a focus in the months of blooming (Welker et al. 2021, 642).

Our analyses for a presence of cyanotoxins showed presence of microcystins in all the water bodies (Table 4$)$. The largest reported quantity is in OR $\left(6 \mu \mathrm{g} \mathrm{L}^{-1}\right)$, followed by AVR $\left(2 \mu \mathrm{g} \mathrm{L}^{-1}\right)$, SL $\left(0.2 \mu \mathrm{g} \mathrm{L}^{-1}\right)$, and LR (o.17 $\mu \mathrm{g} \mathrm{L}^{-1}$ ). We reported cylindrospermopsin in two of the water reservoirs - AVR (o.15 $\mu \mathrm{g} \mathrm{L}^{-1}$ ) and OR (o.10 $\mu \mathrm{g} \mathrm{L}^{-1}$ ), while we detected saxitoxins in SL $\left(0.10 \mu \mathrm{g} \mathrm{L}^{-1}\right)$ and AVR $\left(0.02 \mu \mathrm{g} \mathrm{L}^{-1}\right)$. The presence of cyanotoxins in the studied water bodies is a logical consequence of the intensive development of cyanobacterial species (a great part of which produce toxins) during the whole summer season, or at the end of the summer (Table 3).

The concentrations of toxins we reported, do not exceed the maximum acceptable values in recreational water: for microcystin LR-24 $\mu \mathrm{g} \mathrm{L}^{-1}$; cylindrospermopsin-6 $\mu \mathrm{g}$ $\mathrm{L}^{-1}$; and saxitoxins-30 $\mu \mathrm{g} \mathrm{L}^{-1}$ (WHO 2020, $40,21,18)$. In connection to this, we should highlight that in our study, we detected toxins, only in September. Studies on the seasonal pattern of microcystin production in cyanobacterial biomass, revealed that in the summer season, their concentrations in Microcystis populations usually decrease (Ibelings et al. 2021, 268). Meanwhile, in OR, we registered intensive blooms of Microcystis spp. during the whole summer. That is why, the microcystin levels should be monitored from the beginning of the season. Furthermore, the waters of the lowland reservoirs/lake we studied are used for irrigation, fishing, fish-farming, and recreation.

Although the concentrations of cyanotoxins are lower than the maximum acceptable values, we think that there is a necessity to monitor programmes for $\mathrm{Cy}$ anobacteria and the toxins they produce, especially in water bodies, which are used for drinking-water supply, recreation, and fish-farming.

\section{Conclusion}

This research analyses phytoplankton communities in four lowland reservoirs/lake in Bulgaria, for the presence of cyanobacterial blooms and cyanotoxin levels. The waters are used for irrigation, fishing, fish-farming, and recreation. Cyanotoxin assays showed the exposition of microcystins in all the four studied water bodies. However, concentrations of cyanotoxins do not exceed the maximum acceptable values in recreational waters. We should note though, that the biovolumes of cyanobacteria and the levels of toxins, place Onogur Reservoir, Asparuhov Val Reservoir, and Srebarna Lake on "Alert Level 1", which recommends cyanotoxin monitoring, with a focus on the periods of blooming.

Author Contributions: Conceptualization, D.B. and I.T.; Methodology, D.B. and I.T.; Validation, D.B. and I.T.; Formal Analysis, S.K. and S.S.; Investigation, D.B., I.T., S.K. and S.S.; Writing - Original Draft Preparation, D.B.; Writing Review \& Editing, I.T.; Visualization, S.K. and S.S.; Supervision, D.B. All authors have read and agreed to the published version of the manuscript.

Funding: This work was supported by the project "Provision of data for 2018 from hydrobiological monitoring of surface waters, in accordance with an order of the Minister of Environment and Water", Contract No 3642 I 25.10.2018

Institutional Review Board Statement: Not applicable.

Conflicts of Interest: The founding sponsors had no role in the design of the study; in the writing of the manuscript, and in the decision to publish the results.

\section{References}

Belkinova, Detelina, Rumen Mladenov, and Svetoslav Chesmedjiev. 2013. "Phytoplankton.” In Biological analysis and ecological assessment of surface water types in Bulgaria, edited by Detelina Belkinova and Gana Gecheva, 55-96. Plovdiv: Plovdiv University Press. [In Bulgarian]

Chorus, Ingrid, and Emanuela Testai. 2021.

"Recreation and Occupational Activities." In 
Toxic Cyanobacteria in Water, 2nd edition, edited by Ingrid Chorus and Martin Welker, 333-367. Geneva: CRC Press, Boca Raton (FL), on behalf of the World Health Organisation.

Chorus, Ingrid, and Martin Welker. 2021. Toxic Cyanobacteria in Water, 2nd edition. Geneva: CRC Press, Boca Raton (FL), on behalf of the World Health Organisation.

Descy, Jean-Pierre, Maya Stoyneva-Gärtner, Blagoy Uzunov, Petya H. Dimitrova, Vera Pavlova, and Georg Gärtner. 2018. "Studies on cyanoprokaryotes of the water bodies along the Bulgarian Black Sea Coast (1890-2017): a review, with special reference to new, rare and harmful taxa." Acta Zoologica Bulgarica 11: 43-52.

Dochin, Kostadin, and Maya Stoyneva. 2016. "Phytoplankton of the reservoir 'Dospat' (Rodopi $\mathrm{mts}$, Bulgaria) as an indicator of a negative trend in reservoir development due to long-term cage fishfarming." Annual of Sofia University "St. Kliment Ohridski" Faculty of biology, Book 2 - Botany 99: 47-60.

Guiry, Michael, and G.M. Guiry. 2013. "AlgaeBase. World-Wide Electronic Publication.” National University of Ireland, Galway. Accessed March 05, 2021. http://www.algaebase.org.

Hillebrand, Helmut, Claus-Dieter Dürseken, David Kirschtel, Utsa Pollingher, and Tamar Zohary. 1999. "Biovolume calculation for pelagic and benthic microalgae." Journal of Phycology 35 (2): 403-424. https://doi. org/10.1046/j.1529-8817.1999.3520403.x.

Humpage, Andrew, and David Cunliffe. 2021. "Drinking-Water." In Toxic Cyanobacteria in Water, 2nd edition, edited by Ingrid Chorus and Martin Welker, 305-332. Geneva: CRC Press, Boca Raton (FL), on behalf of the World Health Organisation. Ibelings, Bastian, Rainer Kurmayer, Sandra Azevedo, Susanna Wood, Ingrid Chorus, and Martin Welker. 2021. "Understanding the occurrence of cyanobacteria and cyanotoxins." In Toxic Cyanobacteria in Water, 2nd edition, edited by Ingrid Chorus, and Martin Welker, 214-294. Geneva: CRC Press, Boca Raton (FL), on behalf of the World Health Organisation.

Michev, Tanyo, and Maya Stoyneva. 2007. Inventory of Bulgarian Wetlands and their Biodiversity. Part 1: Non-Lotic Wetlands. Sofia: Public House Svetlostrouy.
Napiórkowska-Krzebietke, Agnieszka. 2015. "Cyanobacterial bloom intensity in the ecologically relevant state of Lakes - an approach to Water Framework Directive implementation." Oceanological and Hydrobiological Studies 44 (1): 97-108. https://doi.org/10.1515/ohs-2015-0010. Padisák, Judit, Gábor Borics, István Grigorszky, and Éva Soróczki-Pintér. 2006. "Use of phytoplankton assemblages for monitoring ecological status of lakes within the Water Framework Directive: the assemblage index." Hydrobiologia 553: 1-14. https://doi.org/10.1007/s10750-005-1393-9.

Pasztaleniec, Agnieszka. 2016. "Phytoplankton in the ecological status assessment of European lakes - advantages and constraints." Environmental Protection and Natural Resources 27(1): 26-36. https://doi.org/10.1515/OSZN-2016-0004.

Pavlova, Vera, Maya Stoyneva, Vesela Georgieva, Desislav Donchev, Lisa Spoof, Jussi Meriluoto, Zlatka Bratanova, and Irina Karadjova. 2014. "New records of microcystins in some Bulgarian water bodies of health and conservational importance." Journal Water Resource and Protection 6 (5): 446453. https://doi.org/10.4236/jwarp.2014.65044.

Pavlova, Vera, Maya Stoyneva-Gärtner, Blagoy Uzunov, Zlatka Bratanova, Antoaneta Lazarova, and Irina Karadjova. 2015. "Microcystins -LR, -YR and -RR in six Bulgarian water bodies of health and conservational importance (2012-2014)." Journal Water Resource and Protection 7 (16): 1375-1386. https://doi.org/10.4236/jwarp.2015.716111.

Stoyneva-Gärtner, Maya, Jean-Pierre Descy, Adrien Latli, Blagoy A. Uzunov, Vera T. Pavlova, Zlatka Bratanova, Pavel Babica, Blahoslav Maršálek, Jussi Meriluoto, and Lisa Spoof. 2017. "Assessment of cyanoprokaryote blooms and of cyanotoxins in Bulgaria in a 15-year period (2000 - 2015)." Advances in Oceanography and Limnology 8 (1): 131-152. https://doi.org/10.4081/aiol.2017.6320.

Teneva, Ivanka, Diyana Basheva, Detelina Belkinova, Ivanka Dimitrova-Dyulgerova, Rumen Mladenov, and Balik Dzhambazov. 2011. "Study of the qualitative and quantitative composition of the blue-green algae (Cyanoprokaryota), presence of cyanotoxins and heavy metals in Studen kladenets reservoir." Trav. Sci. Univ. Plovdiv - Plantarum 41 (6): 89-124. [In Bulgarian].

Teneva, Ivanka, Detelina Belkinova, Ivanka Dimitrova-Dyulgerova, and Rumen Mladenov. 
2009. "Phytoplankton assemblages and monitoring of cyanotoxins in Trakiets reservoir." Scientific Researches of the Union of Scientists in Bulgaria-Plovdiv, Series B. Natural Sciences and the Humanities 12: 244-249.

Teneva, Ivanka, Detelina Belkinova, Ivanka Dimitrova-Dyulgerova, Milena Vlaknova, and Rumen Mladenov. 2010a. "Composition and toxic potential of Cyanoprokaryota in Vacha Dam (Bulgaria)." Bio-technology \& Bio-technological Equipment 24: 26-32. https://doi.org/10.1080/13 102818.2010.10817804.

Teneva, Ivanka, Gana Gecheva, Svetoslav Chesmedjiev, Plamen Stoyanov, Rumen Mladenov, and Detelina Belkinova. 2014. "Ecological status assessment of Skalenski Lakes (Bulgaria)." Bio-technology $\mathcal{E}$ Bio-technological Equipment 28: 82-95. https:// doi.org/10.1080/13102818.2014.901682.

Teneva, Ivanka, Rumen Mladenov, Detelina Belkinova, Ivanka Dimitrova-Dyulgerova, and Balik Dzhambazov. 2010b. "Phytoplankon community of the drinking after supply reservoir Borovitsa (South Bulgaria) with an emphasis on cyanotoxins and water quality." Central European Journal of Biology 5: 231-239. https:// doi.org/10.2478/s11535-010-0009-1.

Teneva, Ivanka, Plamen Stoyanov, Balik Dzhambazov, Rumen Mladenov, and Detelina Belkinova. 2015. "What is known about Cyanoprokaryota and the algal blooms along the Bulgarian Black Sea coast: an overview." Journal of Bio-Science and Bio-technology 4 (3): 239-244.
Utermöhl, Hans. 1958. "Zur Vervollkommnung der quantitative Phytoplankton-Methodik." Internationale Vereinigung für Theoretische und Angewandte Limnologie: Mitteilungen 9 (1): 1-38. https://doi.org/10.1080/05384680.1958.11904091. Welker, Martin, Ingrid Chorus, Blake Schaeffer, and Erin Urquhart. 2021. "Planning monitoring programmes for cyanobacteria and cyanotoxins." In Toxic Cyanobacteria in Water, 2nd edition, edited by Ingrid Chorus and Martin Welker, 641668. Geneva: CRC Press, Boca Raton (FL), on behalf of the World Health Organisation.

WFD CIS Guidance Document No. 23. 2009 - Guidance Document on Eutrophication assessment in the Context of European Water Policies. Accessed October 15, 2021. https:// circabc.europa.eu/sd/a/9060bdb4-8b66-439ea9b0-a5cfd8db2217/Guidance_document_23 Eutrophication.pdf.

WHO, 2020. Cyanobacterial toxins: Anatoxin- $a$ and analogues; Cylindrospermopsins; Microcystins; Saxitoxins. Background documents for development of WHO Guidelines for Drinkingwater Quality and Guidelines for Safe Recreational Water Environments. Geneva: World Health Organisation. Accessed October 15, 2021. https:// cdn.who.int/media/docs/default-source/washdocuments/wash-chemicals/chem-backgrounddocuments-dec-2020-updated.pdf. 